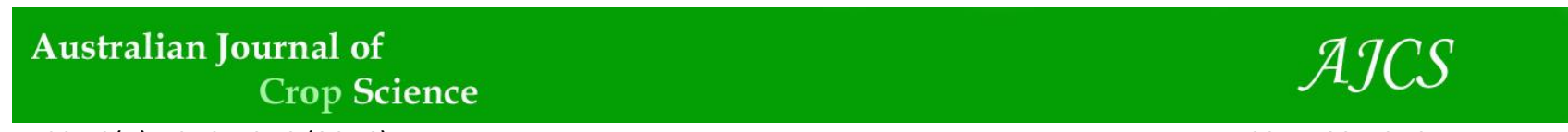

AJCS 10(7):1040-1046 (2016)

ISSN:1835-2707

DOI: $10.21475 /$ ajcs.2016.10.07.p7732

\title{
Specific demands to the traction of cutting discs and furrow openers for the no-tillage system
}

\author{
Tiago Rodrigo Francetto ${ }^{1 *}$, Airton dos Santos Alonço ${ }^{1}$, Dauto Pivetta Carpes ${ }^{1}$, Otávio Dias da Costa \\ Machado $^{2}$, Rafael Sobroza Becker ${ }^{1}$, Catize Brandelero ${ }^{1}$
}

1Universidade Federal de Santa Maria (UFSM), Post graduation Program in Agricultural Engineering, City of
Santa Maria, State of Rio Grande do Sul, Brazil

2Instituto Federal do Rio Grande do Sul (IFRS), City of Bento Gonçalves, State of Rio Grande do Sul, Brazil

*Corresponding author: tiagofrancetto@gmail.com

\begin{abstract}
The objective of this study was to identify the specific demands to the traction considering the work depth and the soil area mobilized by different associations between crop residue coulter discs and fertilizer furrow openers of crop planters, for the no-tillage system, subject to the ground speed. This experiment was conducted in a farm in the city of Santa Maria (Brazil - Rio Grande do Sul), in a soil classified as Red Ultisol with sandy loam texture. The experiment consisted of 24 combinations of treatments, in a factorial design of $2 \times 3 \times 4$. The treatments were obtained by the interaction of furrowers (hoe furrow opener and double-disc opener) with three arrangements in relation to the cutting discs (without disc, smooth and offset fluted coulter) and speeds (1.11, 1.67, 2.22 and 2.78 $\mathrm{m}$ $\left.\mathrm{s}^{-1}\right)$. The combination of mechanisms was possible through the coupling in a mobile tool holder structure and by using an instrumented tractor as a power source. There was a significant influence of all factors on the variables. The double-disc presented the highest specific demand due to the depth, with $24.08 \mathrm{kN} \mathrm{m}^{-1}$, while the hoe opener required $19.09 \mathrm{kN} \mathrm{m}^{-1}$. For the need of traction per mobilized soil area, the double-disc opener also had superior requirement, 9.94\% higher. Therefore, the hoe opener is more efficient in the use of traction. The use of cutting discs integrated with this furrow opener reduced the extension of the demands and provided lower speed influence, while the opposite happens for the double-disc furrow opener. Regardless of the combination, an increment of variables was observed with the increase of speed.
\end{abstract}

Keywords: row crop planter; mismatched double-disc; hoe type fertilizer furrow opener; tractive force; soil mobilization.

Abbreviations: SF_fixed furrow opener; SR_mismatched double-disc; DL_smooth coulter; DO_offset fluted; SD_ no coulter

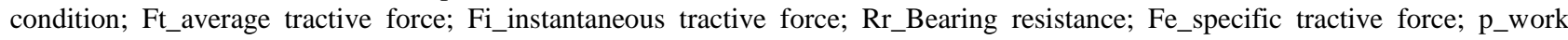
depth; Reo_specific operational resistance; Am_mobilized soil area.

\section{Introduction}

Tractive force can be defined as the amount of force necessary to pull or push a certain tool. The energy requirements of soil preparation operations depend on the type of soil and the handling it has previously experienced. In addition, Andreolla and Gabriel Filho (2006), Mak, Chen and Sadek (2012) and Francetto et al. (2015), concluded that the tractive force is also influenced by the type of trenching mechanism employed in the seeder, as well as the soil physical conditions, as it is affirmed by Conte et al. (2011) and Seidi (2012), and by the work depth (Chen; Munkholm; Nyord, 2013). These factors are very important, especially with the use of the no-tillage system (Altikat; Celik; Gozubuyuk, 2013), considering that, according to Francetto (2014), they are the ones that determine the choice of association between the cutting mechanisms of the crop residues and the opening of a furrow. Thus, for Chen, Munkholm and Nyord (2013), the understanding of the behavior of these tools is extremely important for the development of high performance mechanisms.

According to Andreolla and Gabriel Filho (2006), when analyzing the traction demand of a seeder equipped with several trenching elements, it was found that the double-disc opener, with $6.22 \mathrm{kN}\left(0.69 \mathrm{kN} \mathrm{row}^{-1}\right)$, required lower force in comparison with the hoe furrow opener, with $27.06 \mathrm{kN} \mathrm{(3.01}$
$\mathrm{kN}^{-1}$ row $^{-1}$ ). Moreover, the power required in the bar was also higher for the hoe opener, representing $31.83 \mathrm{~kW}(3.54 \mathrm{~kW}$ row $\left.^{-1}\right)$, while for the discs this demand was $8.02 \mathrm{~kW}(0.90$ $\mathrm{kW}$ row $\left.^{-1}\right)$. Levien et al. (2011), also concluded that the opening of grooves through the use of hoe type furrow opener increases the demands of tractive force in relation to the employment of the double-disc. Evaluating the straw cutting mechanisms, Silva et al. (2012) showed that the offset fluted coulters need a higher horizontal force to break the resistance of the soil in comparison to the smooth disc, possibly because of the design of the disc and its dynamic action on the soil and contact area are different. Besides that, Germino and Benez (2006) concluded that the presence of disc does not change the traction demands by hoe opener, being $0.77 \mathrm{kN}$ for situations with disc and $0.78 \mathrm{kN}$ for the conditions without the mechanism.

The behavior analysis regarding the traction demand among tools or association of mechanisms of the soil/machine relation which perform the same functions, but work in uneven depths, which will cause different soil mobilization areas, must be carried out so that the regulating does not interfere in the interpretations. Therefore, it is necessary to identify the ratio between the requirement of traction and the working depth and the mobilized soil area, 
which will enable a more appropriate and accurate comparison of the energy performance needed by the different tools and their associations. This way, the objective of this study was to identify the demand of traction considering the work depth (specific tractive force) and the mobilized soil area (operational specific resistance) through different associations between cultural residue cutting discs and fertilizer furrow openers of row crop planters, for the notillage system, according to the ground speed.

\section{Results and discussion}

\section{Analysis of variance}

The variance analysis of the variables (ANOVA), with their respective averages, levels and $F$ tests results are presented on Table 1. It was observed a normality of the data and homogeneity of variances.

All the factors presented a significant influence to the level of $1 \%$ probability on the demands of specific tractive force and specific operational resistance, the effects on those variables not being attributed to isolated factors, but by the interaction among them. In addition, for presenting a variation coefficient of 11.60 and $15.63 \%$, the experimental error magnitude can be evaluated as low, providing a high experimental accuracy to the trials, especially due to $\mathrm{Fe}$ and Reo being the result of a ratio between two independent variables, which could impair the experiment precision. Troger et al. (2012), when analyzing specifically the tractive forces in hoe openers, also in the field, obtained an average variation coefficient of $12.43 \%$, and Germino \& Benez (2006) obtained $10.16 \%$ evaluating the interaction between hoe furrow openers and cutting discs in the traction demand.

\section{Specific tractive force}

The average requirement of specific tractive force according to the ground speed for the associations, as well as the standard deviation for each one of them, is shown on Figure 3 . It was found that for the speeds of 1.11 and $1.68 \mathrm{~m} \mathrm{~s}^{-1}$ only SFSD presented difference among the other associations of mechanisms, being its average value of 11.72 and $10.38 \mathrm{kN}$ $\mathrm{m}^{-1}$, respectively, which can be related to the greater work depth in comparison to the others. For the other speeds, the associations in the fixed furrow opener presented differences only for SRDL, in the speed of $2.22 \mathrm{~m} \mathrm{~s}^{-1}$, and SFDL for SRDO in the speed of $2.78 \mathrm{~m} \mathrm{~s}^{-1}$. The lowest specific traction demand was seen in the use of the hoe opener with no cutting disc at the speed of $1.68 \mathrm{~m} \mathrm{~s}^{-1}$, not differing from the speed of $1.11 \mathrm{~m} \mathrm{~s}^{-1}$. For the double-disc furrow opener, the condition with the offset fluted coulter presented the lowest demand, with $18.46 \mathrm{kN} \mathrm{m}^{-1}$, not being significantly different from SRSD and SRDL, all of them at the speed of $1.11 \mathrm{~m} \mathrm{~s}^{-1}$.

The hoe type furrow opener, working without cutting discs, presented an elevation in the specific traction demand with the increase in speed, and there was no difference between the two lowest and the two highest ones. When associated to the smooth disc coulter, the demand was kept constant, presenting an average value of $19.01 \mathrm{kN} \mathrm{m}^{-1}$. When integrated to the offset fluted coulter, the highest speeds provided a significantly higher requirement than the lowest ones, going from $19.26 \mathrm{kN} \mathrm{m}^{-1}$ to $24.80 \mathrm{kN} \mathrm{m}^{-1}$, which can be related to the greatest contact area with the soil enabled by this mechanism, so there is a larger area of mobilized soil, demanding greater tractive force (Francetto et al., 2015). This condition was also evidenced when associated to the doubledisc furrow opener, with an initial value of $18.46 \mathrm{kN} \mathrm{m}^{-1}$ in the speed of $1.11 \mathrm{~m} \mathrm{~s}^{-1}$ to $28.16 \mathrm{kN} \mathrm{m}^{-1}$ in the speed of $2.78 \mathrm{~m}$ $\mathrm{s}^{-1}$. For the condition without disc, the speed did not provide an increase in the demand, remaining in an average value of $20.69 \mathrm{kN} \mathrm{m}^{-1}$. When associated to the smooth disc, it also presented a conservation of demand, with the exception at the speed $2.22 \mathrm{~m} \mathrm{~s}^{-1}$, where there was a significant elevation that may have occurred because of the unexpected reduction of the work depth and elevation of traction demand. The association between smooth cutting disc and the double-disc furrow opener was the one that presented the greatest amplitude $\left(13.68 \mathrm{kN} \mathrm{m}^{-1}\right)$ in the demand of specific tractive force at the different speeds, followed by the hoe opener $\left(11.32 \mathrm{kN} \mathrm{m}^{-1}\right)$ and the interaction between double-disc and offset fluted coulter $\left(9.70 \mathrm{kN} \mathrm{m}^{-1}\right)$. SRSD was the one that presented the lowest amplitude, with $3.11 \mathrm{kN} \mathrm{m}^{-1}$, followed by SFDL, with $3.40 \mathrm{kN} \mathrm{m}^{-1}$, and SFDO, with $5.53 \mathrm{kN} \mathrm{m}^{-1}$.

For all associations, with the exception of the SRDO, there is, in general, a segregation of the speeds between the slowest and the fastest ones in the demand of specific tractive force, shown by the average amplitude between the requirements of speeds 1.11 and $1.68 \mathrm{~m} \mathrm{~s}^{-1}$ and 2.22 and $2.78 \mathrm{~m} \mathrm{~s}^{-1}$. Thus, associated to the fact that this latter group demands high $\mathrm{Fe}$, the speed increase from $1.11 \mathrm{~m} \mathrm{~s}^{-1}$ to $1.68 \mathrm{~m} \mathrm{~s}^{-1}$, in the referred associations of furrow opener/disc, is not a limiting factor for the correct formation of sowing furrow. For the SRDO, the Fe demand showed a proportional behavior to the unitary increase of speed, which indicates the need for a more careful choice in it, so that the formation of inappropriate furrow to the seed deposition can be avoided.

The mathematical function that describes the performance of the associations regarding the specific traction requirement related to the speed, the measurement of the proximity degree $\left(R^{2}\right)$ and its first derivative, besides the inclination of the line of the derivative function in relation to axis $y$, are shown on Table 3. The determination coefficients had an average of $78.34 \%$, the interaction between SRDO having the best proximity for the function, with $99.49 \%$, followed by SFDL, with $90.19 \%$, and the SRDL with $89.70 \%$. Only the SRSD association showed a correlation inferior to $82.00 \%$, with $23.69 \%$, considering the elevated standard deviation obtained in this combination. This way, with the exception of this one, it can be said that the verifications to be carried out by prediction will have an effective equivalence with the real values, because the dispersions occur close to the models tendency lines.

Based on the inclination of the line of the derivative function, it was evidenced that the interactions between the hoe furrow opener without disc and the double-disc furrow opener with smooth cutting disc are the associations between disc/furrow opener that undergo the greatest proportional influence in their demand for specific tractive force due to the increase in speed. Besides this, the furrow openers, when associated with the offset fluted coulter, also presented great influence of the speed on the Fe demands. On the other hand, working in association with the smooth cutting disc, the hoe opener presented the lowest influence in the demand according to the increase in speed, followed by the condition of double-disc without disc. Thus, the use of cutting discs decreased, for the associations with the hoe opener, and increased, for the associations with double-disc furrow opener, the influence of the increase in speed on the demand of specific tractive force.

The graphic representation of the performance of the associations regarding the Fe requirement with the increase in the ground speed is shown on Figure 4. The shaded area represents the typical range of speed for the practice of the 
Table 1. Synthesis of the variance analysis with the average of the factors, their levels and the results of the $\mathrm{F}$ test.

\begin{tabular}{|c|c|c|}
\hline Factors & Specific force $\left(\mathrm{kN} \mathrm{m}^{-1}\right)$ & Specific operational resistance $\left(\mathrm{kN} \mathrm{m}^{-2}\right)$ \\
\hline \multicolumn{3}{|l|}{ FURROW OPENERS } \\
\hline Fixed (SF) & $19.09 \mathrm{~b}$ & $170.51 \mathrm{~b}$ \\
\hline Rotary (SR) & $24.08 \mathrm{a}$ & $187.46 \mathrm{a}$ \\
\hline \multicolumn{3}{|l|}{ CUTTING DISCS } \\
\hline No disc (SD) & $18.62 \mathrm{~b}$ & $156.19 \mathrm{~b}$ \\
\hline Smooth disc (DL) & $23.47 \mathrm{a}$ & $198.15 \mathrm{a}$ \\
\hline Offset fluted coulter (DO) & $22.66 \mathrm{a}$ & $182.61 \mathrm{a}$ \\
\hline \multicolumn{3}{|l|}{ SPEED } \\
\hline $1.11 \mathrm{~m} \mathrm{~s}^{-1}$ & $18.09 \mathrm{~b}$ & $169.32 \mathrm{bc}$ \\
\hline $1.67 \mathrm{~m} \mathrm{~s}^{-1}$ & $19.65 \mathrm{~b}$ & $159.12 \mathrm{c}$ \\
\hline $2.22 \mathrm{~m} \mathrm{~s}^{-1}$ & $24.16 \mathrm{a}$ & $193.23 \mathrm{ab}$ \\
\hline $2.78 \mathrm{~m} \mathrm{~s}^{-1}$ & $24.44 \mathrm{a}$ & $194.27 \mathrm{a}$ \\
\hline \multicolumn{3}{|l|}{$\mathrm{VC}, \mathrm{SD}$ and $\mathrm{MG}$} \\
\hline Variation Coefficient (VC) $(\%)$ & 11.60 & 15.63 \\
\hline Standard Deviation (SD) & 5.56 & 38.77 \\
\hline General average (MG) & 21.59 & 178.99 \\
\hline \multicolumn{3}{|l|}{ F test } \\
\hline Furrow opener $(\mathrm{F} 1)$ & $71.41 * *$ & $6.61 *$ \\
\hline Cutting disc $(\mathrm{F} 2)$ & $25.77 * *$ & $13.80 * *$ \\
\hline Speed (F3) & $29.42 * *$ & $7.09 * *$ \\
\hline $\mathrm{F} 1 \times \mathrm{F} 2$ & $12.36 * *$ & $1.83 \mathrm{~ns}$ \\
\hline $\mathrm{F} 1 \times \mathrm{F} 3$ & $2.26 \mathrm{~ns}$ & $0.08 \mathrm{~ns}$ \\
\hline $\mathrm{F} 2 \times \mathrm{F} 3$ & $1.92 \mathrm{~ns}$ & $0.89 \mathrm{~ns}$ \\
\hline $\mathrm{F} 1 \times \mathrm{F} 2 \times \mathrm{F} 3$ & $8.09 * *$ & $4.26 * *$ \\
\hline
\end{tabular}

Means followed by the same letter in the column do not differ significantly from each other by the Tukey test $(\mathrm{p}<0.005)$.

NS: not significant $(\mathrm{P}>0.05) ;{ }^{*}$ : significant $(\mathrm{P}<0.05) ;{ }^{* *}$ : significant $(\mathrm{P}<0.01)$;

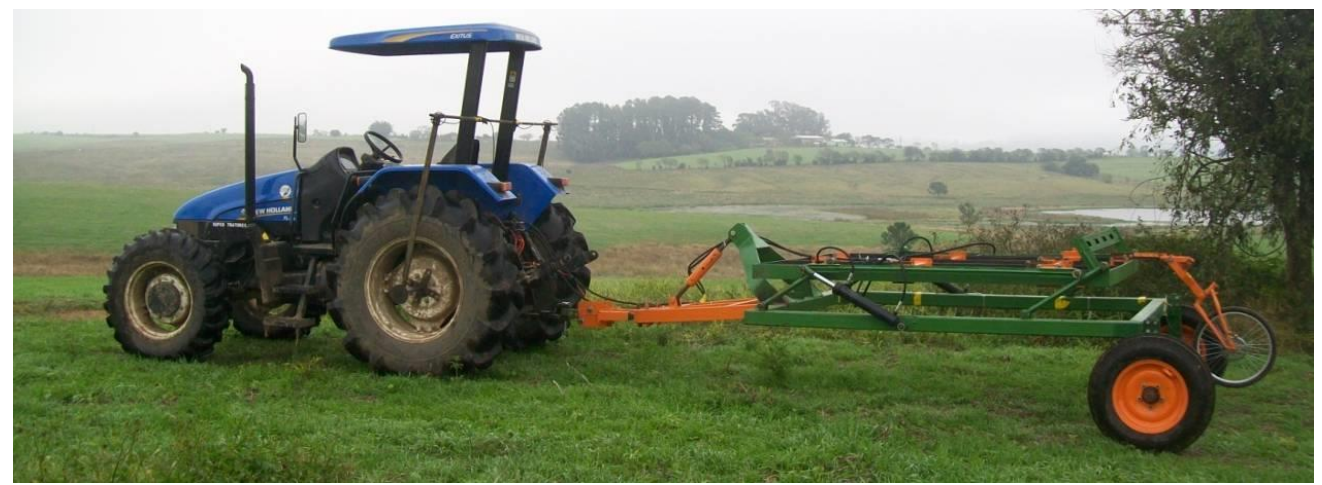

Fig 1. Tractor/instrumented tool holder set used in the tests.

sowing operation. All the disc/furrow opener associations presented an increase in the demand of specific tractive force with the increase of ground speed, with a greater significance for the integrations SFSD, SRDL, SFDO, and SRDO, in a defined order.

In the ranges of typical speeds, the hoe opener presented a better performance when associated with the smooth cutting disc, considering the maintenance in the demand of Fe with the increase in speed, in comparison with the integration of the offset fluted coulter or working in isolation. For the double-disc furrow opener, the association with cutting discs provided an increase in the demand, while when working in isolation, it kept the Fe demand with the increase in speed.

\section{Specific operational resistance}

Figure 5 shows the requirement for specific operational resistance for the associations between furrow opener/cutting disc, as well as the standard deviation, considering the travel speed.
The associations between the fixed furrow opener and smooth and offset fluted coulter, besides the rotary furrow opener without disc and with offset fluted coulter, did not present any influence of the speed on the specific resistance. On the other hand, the combinations of hoe furrow opener without disc and double-disc with smooth disc provided an increment in the variable due to the increase in speed. Also, the hoe opener without using any cutting disc was the combination, at the speed of 1.11 and $1.67 \mathrm{~m} \mathrm{~s}^{-1}$, that presented the smallest resistance value, with 125.17 and $100.77 \mathrm{kN} \mathrm{m}^{-2}$, respectively. In the following speed, $2.22 \mathrm{~m} \mathrm{~s}^{-}$ 1 , the combinations that employed the fixed furrow opener and the condition of the rotary furrow opener without disc were the ones that obtained the smallest numbers of power demand values per mobilized soil area. In the speed of $2.78 \mathrm{~m}$ $\mathrm{s}^{-1}$, there was no statistical difference among the combinations of furrow opener/disc.

The greatest amplitude of Reo was verified for the association between the double-disc furrow opener and smooth cutting disc, with $68.59 \mathrm{kN} \mathrm{m}^{-2}$, followed by the hoe opener working without a cutting $\operatorname{disc}\left(58.45 \mathrm{kN} \mathrm{m}^{-2}\right)$ and the 
Table 2. Mathematical function that describes the Fe demand of the associations.

\begin{tabular}{lllll}
\hline Associations & \multicolumn{1}{c}{ Mathematical function } & $\mathrm{R}^{2}$ & $\begin{array}{c}\text { First derivative of the } \\
\text { function }\end{array}$ & $\begin{array}{c}\text { Inclination of the line in } \\
\text { relation to } \mathrm{y} \text { axis }\end{array}$ \\
\hline SFSD & $\mathrm{f}(\mathrm{x})=0.8147 \mathrm{x}^{2}+0.3951 \mathrm{x}+9.4642$ & 0.8245 & $\frac{\mathrm{dy}}{\mathrm{dx}}=1.6294 \mathrm{x}+0.3951$ & $31.54^{\circ}$ \\
SFDL & $\mathrm{f}(\mathrm{x})=0.0686 \mathrm{x}^{2}+0.6778 \mathrm{x}+16.801$ & 0.9019 & $\frac{\mathrm{dy}}{\mathrm{dx}}=0.1372 \mathrm{x}+0.6778$ & $82.19^{\circ}$ \\
SFDO & $\mathrm{f}(\mathrm{x})=0.3204 \mathrm{x}^{2}+4.7824 \mathrm{x}+13.855$ & 0.8450 & $\frac{\mathrm{dy}}{\mathrm{dx}}=0.6408 \mathrm{x}+4.7824$ & $57.38^{\circ}$ \\
SRSD & $\mathrm{f}(\mathrm{x})=0.1493 \mathrm{x}^{2}-0.1028 \mathrm{x}+19.834$ & 0.2369 & $\frac{\mathrm{dy}}{\mathrm{dx}}=0.2986 \mathrm{x}+0.1028$ & $73.37^{\circ}$ \\
SRDL & $\mathrm{f}(\mathrm{x})=-0.812 \mathrm{x}^{2}+9.2058 \mathrm{x}+13.173$ & 0.8970 & $\frac{\mathrm{dy}}{\mathrm{dx}}=-1.624 \mathrm{x}+9.2058$ & $31.69^{\circ}$ \\
SRDO & $\mathrm{f}(\mathrm{x})=-0.2937 \mathrm{x}^{2}+4.7824 \mathrm{x}+13.855$ & 0.9949 & $\frac{\mathrm{dy}}{\mathrm{dx}}=-0.5874+4.7824$ & $59.46^{\circ}$
\end{tabular}

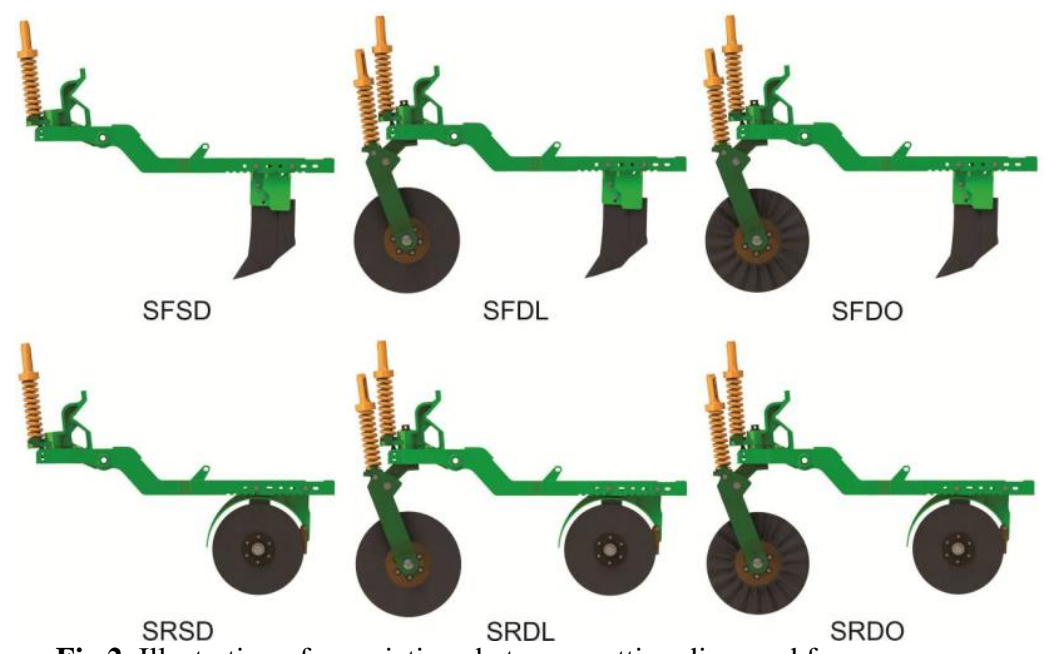

Fig 2. Illustration of associations between cutting discs and furrow openers.

double-disc furrow opener integrated with the offset fluted coulter $\left(42.48 \mathrm{kN} \mathrm{m}^{-2}\right)$. The other associations between furrow openers and cutting discs (SFDL, SFDO, SRSD) did not present significant amplitudes with the increase in speed. Thus, the use of cutting discs associated to the hoe opener provided a decrease in the Reo extension, while when associated with double-disc causes the increase of this extension, especially for the condition with the smooth disc. This fact can be explained because the use of cutting discs associated to the hoe opener provides a reduction in the increment of traction demand and maintenance of the soil mobilization with the increment of travel speed, according to Francetto et al. (2015). The mathematical function that describes the performance of the associations regarding the specific operational resistance according to the speed, the measurement of the proximity degree $\left(\mathrm{R}^{2}\right)$ and its first derivative, besides the inclination of the line of the derivative function in relation to axis $y$, are shown on Table 4 . The determination coefficients had an average of $75.56 \%$, the interaction between SRSD having a greater proximity for the function, with $98.56 \%$, followed by SFDO, with $95.80 \%$, and the SFDO with $78.16 \%$. Only the SFDL association showed a correlation inferior to $50.00 \%$, with $49.04 \%$, considering the elevated standard deviation obtained in this combination. Thus, with the exception of this one, it can be said that the verifications to be gained by prediction will have an effective equivalence with the real values, because the dispersions occur close to the tendency lines of the models. The graphic representation of the performance of associations regarding the Reo requirement with the increase of speed is shown on Figure 6. The shaded area represents the typical range of ground speed for the practice of the sowing operation. In short, regardless of the combination between the furrow opener and the cutting disc, it was observed an increment in the need of traction per mobilized soil area, and this increase was more greatly found between the travel speeds of 1.67 and $2.22 \mathrm{~m} \mathrm{~s}^{-1}$. However, in the typical speed range, the interactions SFDL and SFDO presented Reo maintenance, despite the values obtained for them being superior to the values obtained when this furrow opener worked without a cutting disc. Nevertheless, the interactions with the rotary furrow opener presented higher values than the ones found with the hoe opener.

\section{Materials and methods}

\section{Experiment area}

The experiment was done in a farm located in the city of Santa Maria (State of Rio Grande do Sul/Brazil). As soil cover it was observed the existence of soybean (Glycine max) 
Table 3. Mathematical function that describes the Reo demand of the associations.

\begin{tabular}{lcccc}
\hline Associations & \multicolumn{1}{c}{ Mathematical function } & $\mathrm{R}^{2}$ & $\begin{array}{c}\text { First derivative of the } \\
\text { function }\end{array}$ & $\begin{array}{c}\text { Inclination of the line } \\
\text { in relation to } \mathrm{y} \text { axis }\end{array}$ \\
\hline SFSD & $\mathrm{f}(\mathrm{x})=4.3048 \mathrm{x}^{2}+5.013 \mathrm{x}+105.27$ & 0.6162 & $\frac{\mathrm{dy}}{\mathrm{dx}}=8.6096 \mathrm{x}+5.013$ & $6.63^{\circ}$ \\
SFDL & $\mathrm{f}(\mathrm{x})=-2.2321 \mathrm{x}^{2}+8.3944 \mathrm{x}+176.80$ & 0.4904 & $\frac{\mathrm{dy}}{\mathrm{dx}}=-4.4642 \mathrm{x}+8.3944$ & $12.63^{\circ}$ \\
SFDO & $\mathrm{f}(\mathrm{x})=1.6499 \mathrm{x}^{2}+0.653 \mathrm{x}+166.39$ & 0.7816 & $\frac{\mathrm{dy}}{\mathrm{dx}}=3.2998 \mathrm{x}+0.653$ & $16.86^{\circ}$ \\
SRSD & $\mathrm{f}(\mathrm{x})=19.605 \mathrm{x}^{2}-99.061 \mathrm{x}+262.92$ & 0.9856 & $\frac{\mathrm{dy}}{\mathrm{dx}}=39.21 \mathrm{x}-99.061$ & $1.46^{\circ}$ \\
SRDL & $\mathrm{f}(\mathrm{x})=4.6346 \mathrm{x}^{2}+6.1155 \mathrm{x}+174.19$ & 0.7019 & $\frac{\mathrm{dy}}{\mathrm{dx}}=9.2692 \mathrm{x}+6.1155$ & $6.16^{\circ}$ \\
SRDO & $\mathrm{f}(\mathrm{x})=-2.1277 \mathrm{x}^{2}+25.868 \mathrm{x}+136.12$ & 0.9580 & $\frac{\mathrm{dy}}{\mathrm{dx}}=-4.2554+25.868$ & $13.22^{\circ}$ \\
\hline
\end{tabular}

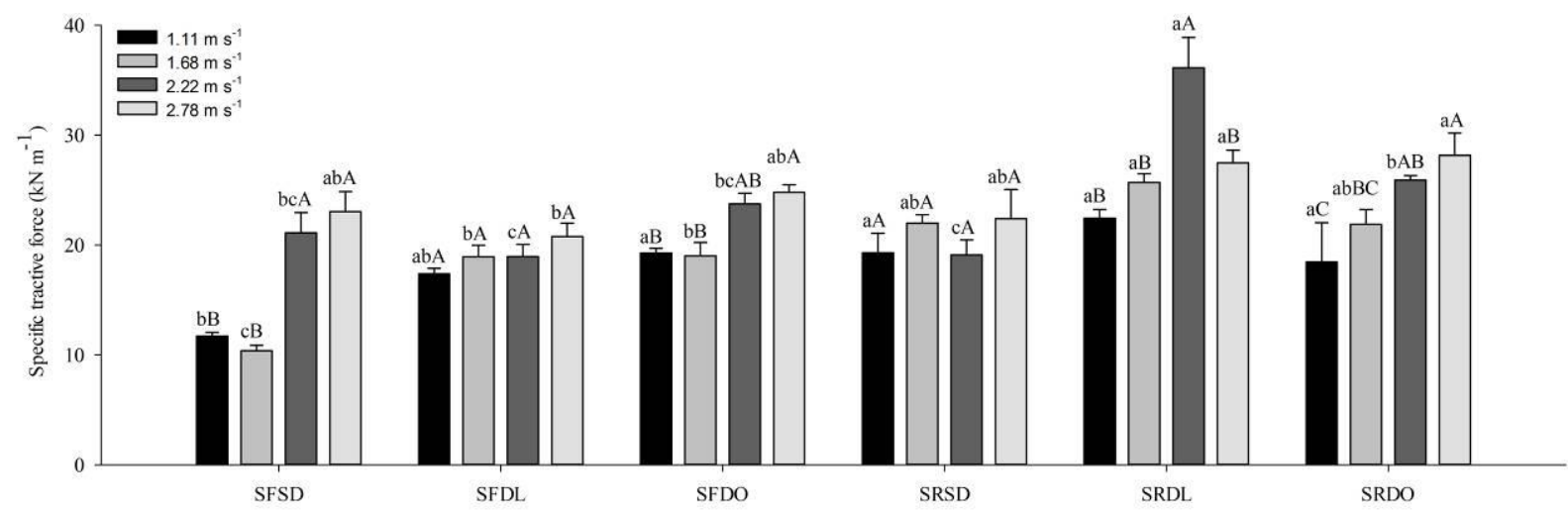

Interactions between cutting discs and furrow opener

Fig 3. Influence of the travel speed on the specific tractive force in the interactions of discs/furrow openers. Averages with the same lower case letter (different associations/same speed) and upper case (different speeds/same association), do not differ significantly from each other by the Tukey test $(\mathrm{p}<0.05) . \mathrm{CV}=11.60 \%$. The bars indicate the standard deviation.

and ryegrass (Lolium multiflorum) straw residue, besides some weeds. Through the greenhouse method, it was found the presence of $287.20 \mathrm{~g} \mathrm{~m}^{-2}$ of dry matter on the soil surface. The physical characterization of the soil was carried out through field sample collection, in a depth of 0 to $0.20 \mathrm{~m}$, in accordance to the methodology proposed by EMBRAPA (1997), to determine the soil density and the water content. For the first, an average value of $1.64 \mathrm{~g} \mathrm{~cm}^{-3}$ was verified, while the second remained at $13.15 \%$. The characterization of the soil texture consisted of adopting Vettori's method. It is composed of $17.59 \%$ clay, $28.44 \%$ silt and $53.97 \%$ sand, and the soil is classified, regarding its texture, as sandy loam. It was classified as Ultisol. The soil penetration resistance was determined with the use of a Falker electronic penetrometer, model PLG 1020, obtaining an average value of 1,220 kPa. The data collection was carried out in the depth of 0 to 0.40 $\mathrm{m}$, with acquisition of data every $0.010 \mathrm{~m}$ of depth.

\section{Motor-mechanized system and mechanisms}

The tractor used to pull the tool holder, developed by Gassen (2011), was a New Holland TL75E Exitus 4x2 with front wheel assist, shipment mass of 3,390 kg (Figure 1). During the experiment, the FWA remained turned off with the tractor operating in normal conditions, without activating the differential lock. The internal pressure of the front tire (12.424) was of $190.0 \mathrm{kPa}$ and the back one (18.4-30) was of $180.0 \mathrm{kPa}$.
The elements of groove opening used were a hoe furrow opener (SF) and mismatched double-disc (SR). The first presents an attack angle of $55^{\circ}$, tip thickness of $20 \mathrm{~mm}$ and a shank of $10 \mathrm{~mm}$. The second shows a $390 \mathrm{~mm}$ diameter, an angle between the discs' rotary plans of $12^{\circ}$ and height from the contact point of $70 \mathrm{~mm}$. The work depth was of $0.12 \mathrm{~m}$ for the first and $0.06 \mathrm{~m}$ for the second. The cutting discs employed were a smooth (DL) and an offset fluted coulter (DO) with 20 waves, and also the no-disc condition (SD). Both had a diameter of $460 \mathrm{~mm}$ and work at a cutting depth of $50 \mathrm{~mm}$. The associations between furrow openers and disc coulters are shown in Figure 2.

\section{Experiment design}

The treatments were made by the interaction of the groove opening mechanisms (SF and SR), crop residue cutting (SD, DL and DO) and ground speeds $(1.11,1.67,2.22$ and $2.78 \mathrm{~m}$ $\left.\mathrm{s}^{-1}\right)$. The experiment design was of randomized blocks comprised of 24 treatments with three repetitions each, organized in a factorial design of $2 \times 3 \times 4$, with a total area of $4,320.00 \mathrm{~m}^{2}$. The parcels were of $180.00 \mathrm{~m}^{2}, 3.0$ meters wide by 60.0 meters long.

\section{Acquisition of performance data}

A Campbell Scientific datalogger, model CR 1000, was used to store data generated by the load cell type $\mathrm{S}$ characteriza- 

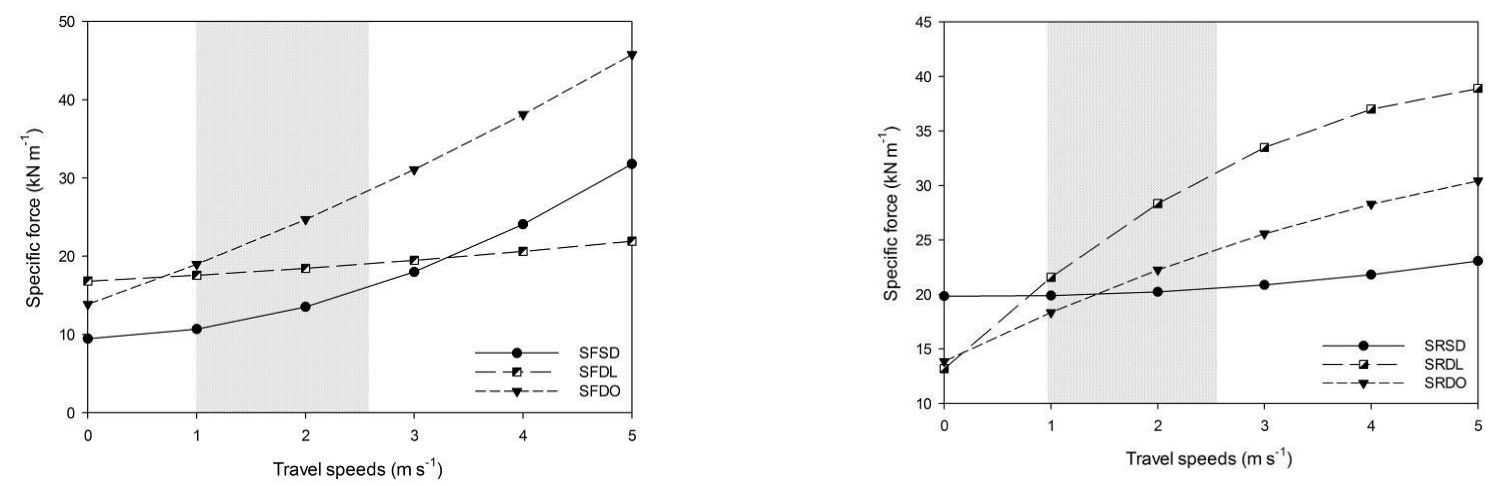

Fig 4. Graphic representation of the mathematical functions that describe Fe demand

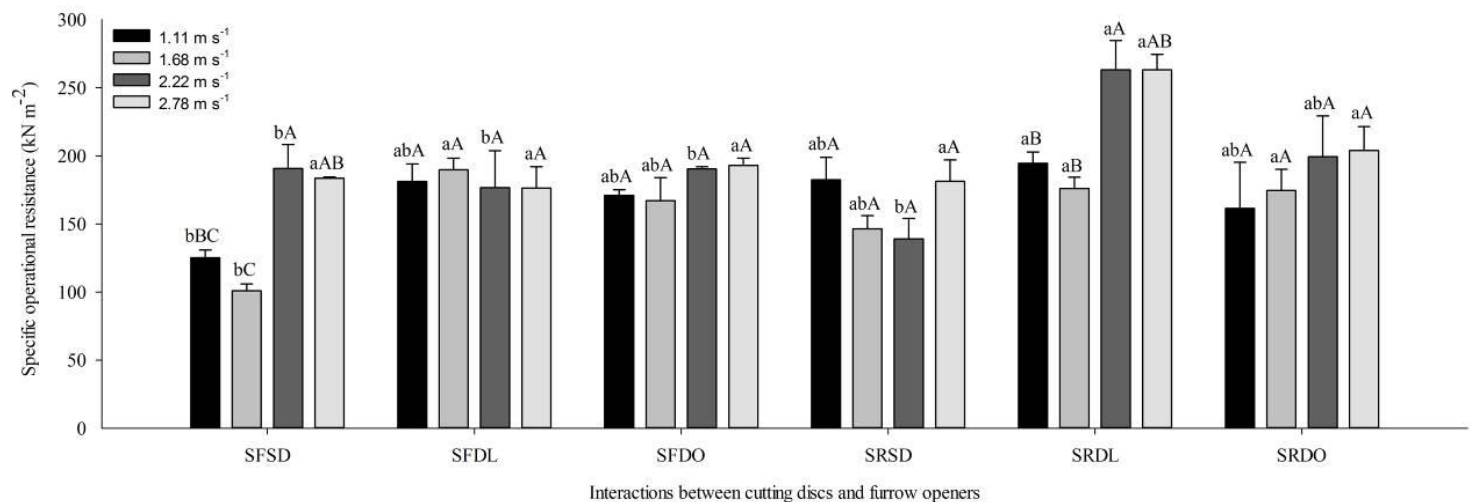

Fig 5. Influence of the travel speed on the specific operational resistance in the interactions of discs/furrow openers. Averages with the same lower case letter (different associations/same speed) and upper case (different speeds/same association), do not differ significantly from each other by the Tukey test $(\mathrm{p}<0.05)$. CV $=15.63 \%$. The bars indicate the standard deviation.
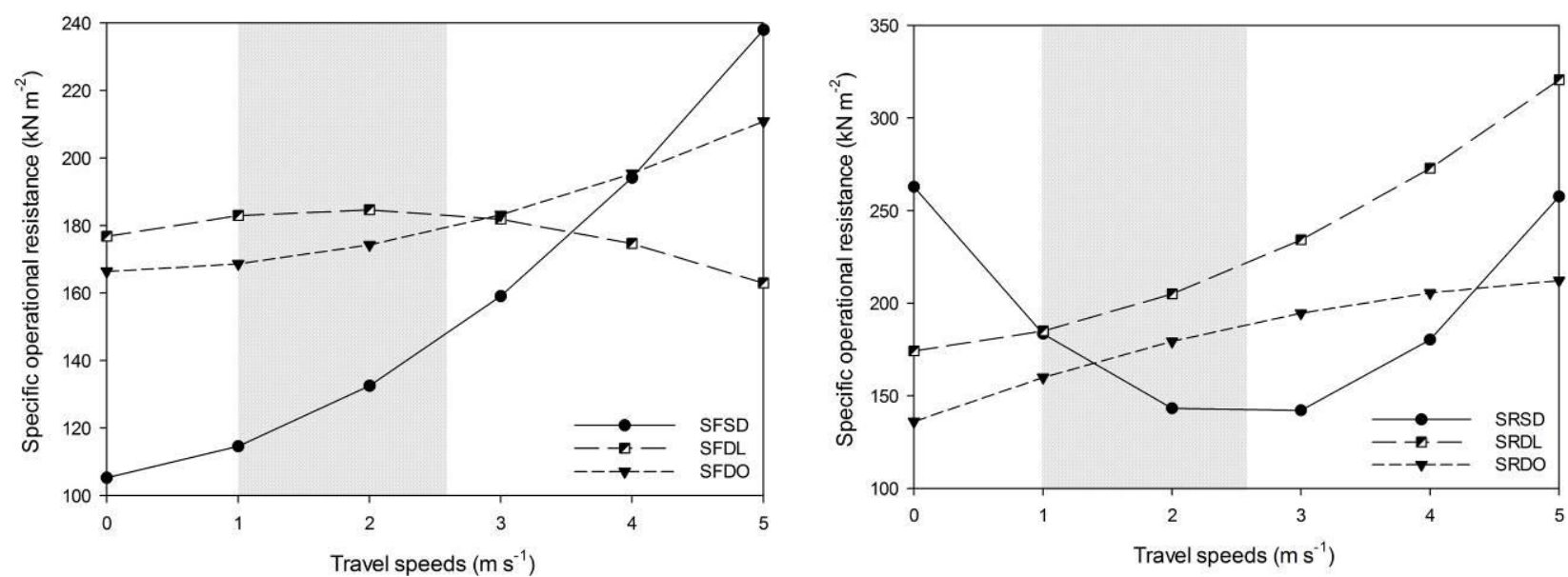

Fig 6. Graphic representation of the mathematical functions that describe Reo's demand.

zation of the traction demand). It was coupled in a retractable support fixed to the traction bar at the head of the tool holder. The implement demanded force for its operation, called bearing resistance, and it was measured at equal amplitude, through electrical signals emitted according to the intensity and taken out from the final value. The average tractive force was determined based on Equation 1, using the instantaneous tractive force and bearing resistance.
$\mathrm{Ft}=\mathrm{Fi}-\mathrm{Rr}$

Where,

$\mathrm{Ft}$, average tractive force $(\mathrm{kN})$

$\mathrm{Fi}$, instantaneous tractive force $(\mathrm{kN})$

$\mathrm{Rr}$, Bearing resistance $(\mathrm{kN})$

The characterization of work depth of the tools was done in three stages: evaluation of the natural profile, mobilized profile and depth identification. The first one was done 
before the passing of the tool holder and the third after it, in the same place, obtaining the geometric form of the furrow. The micro profilometer equipment was used, and in every stage it was successively positioned at the same point, marked by stakes, along the line of passage of the tools. The field evaluation comprehended the installation of the micro profilometer and marking in a A2 graph paper. When the soil natural profile was evaluated, an evaluation point was marked to reposition the equipment after using the tools. After that, the soil was manually removed until the depth where the tool acted, being careful not to alter the profile for the obtaining of the subsurface of the mobilized soil profile.

Afterwards, the profile graphs were photographed, keeping the camera fixed (position $\mathrm{x}, \mathrm{y}$ and $\mathrm{z}$ ). After that, they were inserted in the computing program Auto Cad in order to trace lines of profile contours and, through the use of tools for length reading, the maximum depth of the actuation of the mechanisms was determined.

The average tractive force was determined based on Equation 2 , using the data of the tractive force and work depth.

$$
\mathrm{Fe}=\frac{\mathrm{Ft}}{\mathrm{p}}
$$

Where,

$\mathrm{Fe}$, specific tractive force $\left(\mathrm{kN} \mathrm{m}^{-1}\right)$

$\mathrm{Ft}$, average tractive force $(\mathrm{kN})$

$\mathrm{p}$, work depth (m)

The specific operational resistance was obtained with the use of Equation 3, employing the data of tractive force and the mobilized soil area.

$$
\operatorname{Reo}=\frac{\mathrm{Ft}}{\mathrm{Am}}
$$

Where,

Reo, specific operational resistance $\left(\mathrm{kN} \mathrm{m}^{-2}\right)$

$\mathrm{Ft}$, average tractive force $(\mathrm{kN})$

Am, mobilized soil area $\left(\mathrm{m}^{2}\right)$

\section{Statistical analysis}

After the acquisition of performance data, they were submitted to variance analyses, using the Tukey test at the level of error probability of $5 \%$. The normality of data was tested by using the Kolmogorov-Smirnov test, and the homogeneity of variances was tested by the Cochran test. For those, it was used the Assistat 7.7 beta 2015 software.

\section{Conclusions}

The double-disc furrow opener presented a higher traction demand according to the depth of work and the mobilized soil area than the hoe opener, which certifies that this furrow opener is less efficient in the use of traction. The employment of a cutting disc, when associated to the double-disc, provided a greater amplitude and higher proportional influence of the speed on the demand of specific tractive force and specific operational resistance, and this furrow opener presented a better performance working with the offset fluted coulter. For the hoe opener, it was observed a reduction in this amplitude and lower proportional influence of the speed on these variables when integrated with the cutting discs, in a way that the smooth disc presented the best results.

\section{Acknowledgements}

To the Coordination for the Improvement of Higher Education Personnel (CAPES) for the research financial support.

\section{References}

Altikat S, Celik A, Gozubuyuk Z (2013) Effects of various no-till seeders and stubble conditions on sowing performance and seed emergence of common vetch. Soil Till Res. 126: 72-77.

Andreolla VRM, Gabriel Filho A (2006) Demanda de potência de uma semeadora com dois tipos de sulcadores em áreas compactadas pelo pisoteio de animais no sistema integração lavoura-pecuária. Eng Agríc. 26: 768-776.

Chen Y, Munkholm LJ, Nyord T (2013) A discrete element model for soil-sweep interaction in three different soils. Soil Till Res. 126: 34-41.

Conte O, Levien R, Debiasi H, Stürmer S L K, Mazurana M, Müller J (2011) Soil disturbance index as an indicator of seed drill efficiency in no-tillage agrosystems. Soil Till Res. 114: 37-421.

Embrapa- Empresa Brasileira de Pesquisa Agropecuária (1997) Manual de métodos de análise de solo, $212 \mathrm{p}$.

Francetto TR (2014) Desempenho de mecanismos de corte dos resíduos culturais e abertura de sulco para a semeadura direta. Master's dissertation. Universidade Federal de Santa Maria.

Francetto TR, Alonço A dos S, Bellé MP, Franck CJ, Carpes DP (2015) Comportamento operacional de associações entre sulcadores e discos de corte para sistema de semeadura direta. Eng Agríc. 35: 542-554.

Gassen JRF (2011) Avaliação de ferramenta para escarificação do solo em camadas de forma simultânea. $\mathrm{PhD}$ Thesis. Universidade Federal de Santa Maria.

Germino R, Benez SH (2006) Ensaio comparativo em dois modelos de hastes sulcadoras para semeadoras-adubadoras de plantio direto. Revista Energia na Agricultura. 21: 8592.

Levien R, Furlani CEA, Gamero CA, Conte O, Cavichioli F A (2011) Semeadura direta de milho com dois tipos de sulcadores de adubo, em nível e no sentido do declive do terreno. Ciênc Rural. 41: 1003-1010.

Mak J, Chen Y, Sadek MA (2012) Determining parameters of a discrete element model for soil-tool interaction. Soil Till Res. 118: 117-122.

Seidi E (2012) Effects of geometry of disk openers on seed slot properties. Int J Biol, Biom, Agric, Food Biotec Eng. 12: 1056-1060.

Silva P R A, Benez S H, Jasper S P, Seki A S, Masiero F C, Riquetti N B (2012) Semeadora-adubadora: Mecanismos de corte de palha e cargas verticais aplicadas. Revista Brasileira de Eng Agríc Amb. 16: 1367-1373.

Troger H C H, Reis Â V dos, Machado A L T, Machado R L $\mathrm{T}$ (2012) Analyzing the efforts in furrow openers used in low power planters. Eng Agríc. 32: 1133-1143. 